\title{
SISTEM PENDUKUNG KEPUTUSAN SELEKSI ATLET POOMSAE TAEKWONDO DENGAN METODE ANALITYC HIERACHY PROCESS
}

\author{
Wahyu Joni Kurniawan ${ }^{1}$, Gusrianty ${ }^{2)}$ \\ ${ }^{1,2}$ Teknik Informatika, STIKOM Pelita Indonesia, Jl. A.Yani, Pekanbaru \\ Email : wahyu.jonikurniawan@lecturer.pelitaindonesia.ac.id,gusrianty@lecturer.pelitaindonesia.ac.id
}

\begin{abstract}
Abstrak
The taekwondo martial art has two types of matches, one of them poomsae. To be an athlete requires many criteria to be met, because being an athlete is not easy. With the many criteria that become an indicator of an athlete, then used method of analityc hierarchy process (AHP). Which is the theory of measurement through pairwise comparisons and depends on the expert's judgment to determine priorities. There are several criteria that become a reference for members who want to become poomsae athletes, such as discipline, attitude, craft, technique, endurance, beauty, belt and team. Also some sub belt criteria, namely green, blue, red, and black. Overall, the acquisition of decision data from each alternative is obtained. The end result is that if we take four alternative possibilities, then the yanng selected by weighting is E (042), A (0.23), D (0.16), and B (0, 11). Using this method, will help the coach in selecting which members are more appropriate to be able to follow the match poomsae.
\end{abstract}

Keyword : Decision Support System, Analytical Hierarchy Process, POOMSAE

\begin{abstract}
Beladiri taekwondo memeliki dua jenis pertandingan, salah satunya poomsae. Untuk bisa menjadi atlet maka dibutuhkan banyak kriteria yang harus dipenuhi, dikarenakan menjadi atlet itu tidaklah mudah. Dengan banyaknya kriteria yang menjadi indikator seorang menjadi atlet, maka digunakanlah metode analityc hierarchy process (AHP). Yang merupakan sebuah teori pengukuran melalui perbandingan berpasangan dan bergantung pada penilaian dari para ahli untuk menentukan prioritas. Ada beberpa kriteria yang menjadi acuan bagi anggota yang ingin menjadi atlet poomsae, seperti kedisiplinan, sikap, kerajinan, teknik, daya tahan, keindahan, sabuk dan tim. Juga beberapa sub kriteria dari sabuk, yakni hijau, biru, merah, dan hitam. Secara keseluruhan, pemerolehan data keputusan dari setiap alternatif didapatlah hasil akhirnya adalah jika dimabil 4 alternatif yang memungkinakan, maka yanng terpilih sesuai pembobotan adalah $E(042), A(0,23), D(0,16)$, dan $\mathrm{B}(0,11)$. Dengan menggunakan metode ini, maka akan membantu pelatih dalam memilih anggota manakah yang lebih tepat untuk bisa mengikuti pertandingan poomsae.
\end{abstract}

Kata Kunci : Sistem Pendukung Keputusan, Analityc Hierarchy Process, POOMSAE

\section{PENDAHULUAN}

Dalam seni beladiri taekwondo, terdapat dua jenis pertandingan yang akan dilangsungkan, yakni Kyorugi yang merupakan pertandingan dengan memperlihatkan kecakapan seseorang dalam bertarung, sedangkan Poomsae adalah rangkaian dari teknik gerakan dasar dan pertahanan diri yang dilakukan dengan menghadapi lawan yang imajiner dengan mengikuti diagram tertentu.

Untuk bisa menjadi seorang atlet, maka dibutuhkan keinginan dalam diri untuk berusaha meningkatkan potensi diri dengan melalui kerja keras dan disiplin yang tinggi untuk bisa mempersiapkan diri dalam menghadapi pertandingan. Dengan kerja keras dan disiplin, belumlah cukup untuk bisa memiliki mental atlet dikarenakan masih ada banyak kriteria yang harus dipenuhi untuk bisa mengikuti sebuah pertandingan.

Untuk dapat memilih orang yang tepat, maka dibutuhkanlah sebuah sistem pendukung keputusan yang mana nantinya dapat membantu pelatih dalam menemukan pilihan terbaik dari beberapa alternatif yang layak. Ada berbagai jenis metode dalam memecahkan masalah pengambilan keputusan yang yang memiliki banyak kriteria, salah satunya adalah analityc hierarchy process (AHP). AHP dipilih karena merupakan metode multi-kriteria yang banyak digunakan dan mudah dipahami dan efektif dalam menangani data kualitatif dan kuantitatif. Beberapa penilitian yang pernah dilakukan dengan AHPseperti Implementation of Analytical Hierarchical Process to support decisions in Employee Performance Appraisal(Dalalah. Et.al. 2010),Use of Analytical Hierarchy Process (AHP) to identify the preference of accounting experts regarding the company valuation method in accounting expertise(Claudio, et al. 2016), DSS using AHP in Selection of Lecturer(Adriyendi,etal. 2013)danThe Design Preferences Decision Using the Analytical Hierarchy Process towards Kansei Engineering Approach: Spectacles Design(Fevi Syaifoelida, et al. 2013). 


\section{Landasan Teori}

Decision support system atau Sistem Pendukung Keputusan (SPK) merupakan sistem pendukung keputusan pertama kali diperkenalkan pada awal tahun 1970-an oleh Michael S. Scott Morton dengan istilah Management Decision System (Petrus Wolo et al. 2012).Ditandai dengan sistem interaksi berbasis komputer yang membantu pengambilan keputusan untuk penyelesaian keputusan dalam masalah yang tidak terstruktur. SPK juga merupakan sistem informasi yang interaktif dalam penyediaan informasi, permodelan dan manipulasi data.

Pengambilan keputusan dilakukan dengan pendekatan sistematis terhadap permasalahan melalui proses pengumpulan data menjadi informasi serta ditambah dengan faktor-faktor yang perlu dipertimbangkan dalam pengambilan keputusan (Rika Yunitarini, 2013). Tindakan memilih strategi atau aksi yang diyakini akan memberikan solusi terbaik atas sesuatu itu disebut dengan pengambilan keputusan. Tujuan dari keputusan adalah untuk mencapai target atau aksi tertentu yang harus dilakukan.

Sistem pendukung keputusanadalah sistem berbasis komputer interaktif yangbertindak sebagai sistem pembantu dalam memberikan dukungan untuk kegiatanpengambilan keputusan dan membantu pengambil keputusan dalam mengidentifikasi masalah, menyelesaikannya dan membantu dalam membuat keputusan (Sweta et al. 2012).Sistem pendukung keputusan dapat diimplementasikan untuk membantu pengambil keputusan dalam memanfaatkan data dan model tertentu untuk memecahkan berbagai persoalan yang semi terstruktur dan tidak terstruktur.

Terdapat tiga fase pada proses pengambilan keputusan (Hilyah Magdalena, 2012) :

a. Intelligence, dilakukan penetapan sasaran, pencarian prosedur, pengumpulan data, identifikasi masalah, klasifikasi masalah.

b. Design, diformulasikan model yang akan digunakan dan kriteria yang ditentukan.

c. Choice, lakukan pemilihan modelnya, termasuk model dari solusi.

Analytic Hierarcy Process (AHP) didasarkan pada kemampuan penilaian manusia untuk membangun persepsi hirarki masalah multi-kriteria. Hirarki merupakan suatu representasi dari masalah yang kompleks di dalam sebuah struktur multilevel, yaitu tujuan, faktor, kriteria, sub-kriteria,dan alternatif (Adi Setiawan. et al. 2014).AHP adalah sebuah teori pengukuran melalui perbandingan berpasangan dan tergantung pada penilaian dari para ahli untuk menentukan prioritas. Perbandingan dilakukan dengan menggunakan skala penilaian mutlak yang mewakili berapa banyak suatu elemen terhadap elemen lain berdasarkan atribut yang diberikan.
Prinsip-prinsip dasar dalam penggunaan metode AHP (Muhammad Reza et al. 2014), yakni:

a. Decomposition, memecah masalah menjadi unsur ke bentuk kirarki proses pengambilan keputusan.

b. Comparative Judgement, penilaian tentang kepentingan relatif dua elemen pada suatu tingkat tertentu.

c. Synthesis of Priority, menggunakan eigen vector method untuk mendapat bobot relatif bagi unsur pengambil keputusan.

d. Logical Consistency, karakteristik penting AHP.

\section{HASIL DAN PEMBAHSAN}

Dalam persiapan perhitungan dengan metode AHP, maka dibuatlah struktur hirarki seleksi atlet seperti yang dapat dilihat pada gambar 1, dengan kriteria dan sub kriteria yang digunakan adalah:

1. Kedisiplinan

2. Sikap

3. Kerajinan

4. Teknik

5. Daya Tahan

6. Keindahan

7. Sabuk

8. Tim

Untuk kriteria sabuk, ada 4 sub kriteria, yaitu :
1. Hijau
2. Biru
3. Merah
4. Hitam

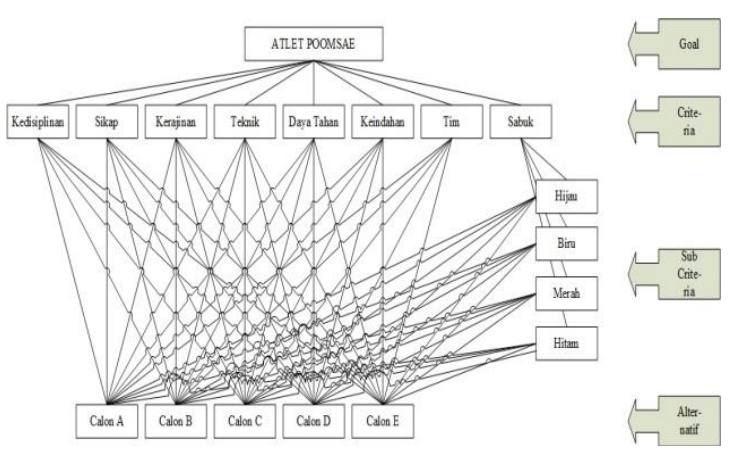

Gambar 1. Hirarki Seleksi Atlet Poomsae

Daristruktur hirarki yang telah dibuat, maka dilakukanlah perbandingan berpasangan untuk mendapatkan nilai pembobotan dari masing-masing kritaria dan alternatif yang digunakan dalam penentuan terpilihnya atlet Poomsae.

Untuk mendapatkan nilai eigen dari perbandingan matriks berpasangan,maka dilakukanpmbandingan nilai dari setiap kriteria, sub kriteria dan alternatif.Untuk matriks berpasangan pada kriteria, bisa dilihat pada tabel 1 . 
Tabel 1. Matrik Berpasangan Kriteria

\begin{tabular}{|l||c|c|c|c|c|c|c|c|}
\hline & Kedisiplinan & Sikap & Kerajinan & Teknik & $\begin{array}{l}\text { Daya } \\
\text { Tahan }\end{array}$ & Keindahan & Sabuk & Tim \\
\hline \hline Kedisiplinan & 1,00 & 2,00 & 3,00 & 5,00 & 5,00 & 5,00 & 7,00 & 7,00 \\
\hline Sikap & 0,50 & 1,00 & 3,00 & 5,00 & 5,00 & 5,00 & 7,00 & 7,00 \\
\hline Kerajinan & 0,33 & 0,33 & 1,00 & 3,00 & 3,00 & 3,00 & 5,00 & 5,00 \\
\hline Teknik & 0,20 & 0,20 & 0,33 & 1,00 & 1,00 & 1,00 & 3,00 & 3,00 \\
\hline Daya Tahan & 0,20 & 0,20 & 0,33 & 1,00 & 1,00 & 1,00 & 3,00 & 3,00 \\
\hline Keindahan & 0,20 & 0,20 & 0,33 & 1,00 & 1,00 & 1,00 & 3,00 & 3,00 \\
\hline Sabuk & 0,14 & 0,14 & 0,20 & 0,33 & 0,33 & 0,33 & 1,00 & 1,00 \\
\hline Tim & 0,14 & 0,14 & 0,20 & 0,33 & 0,33 & 0,33 & 1,00 & 1,00 \\
\hline
\end{tabular}

Setelah melakukan normalisasi pada matriks berpasangan kriteria, maka didapatlah nilai bobotpada matriks berpasangan kriteria, seperti pada yang dapat dilihat pada tabel 2 .

Tabel 2. Nilai Bobot Kriteria

\begin{tabular}{|c|c|c|c|c|c|c|c|c|c|c|}
\hline & Kedisiplinan & Sikap & Kerajiinan & Teknik & \begin{tabular}{|l} 
Daya \\
Tahan
\end{tabular} & Keindahan & Sabuk & Tim & Jumlah & Prioritas \\
\hline Kedisiplinan & 0,37 & 0,47 & 0,36 & 0,30 & 0,30 & 0,30 & 0,23 & 0,23 & 2,57 & 0,32 \\
\hline Sikap & 0,18 & 0,24 & 0,36 & 0,30 & 0,30 & 0,30 & 0,23 & 0,23 & 2,14 & 0,27 \\
\hline Kerajinan & 0,12 & 0,08 & 0,12 & 0,18 & 0,18 & 0,18 & 0,17 & 0,17 & 1,19 & 0,15 \\
\hline Teknik & 0,07 & 0,05 & 0,04 & 0,06 & 0,06 & 0,06 & 0,10 & 0,10 & 0,54 & 0,07 \\
\hline Daya Tahan & 0,07 & 0,05 & 0,04 & 0,06 & 0,06 & 0,06 & 0,10 & 0,10 & 0,54 & 0,07 \\
\hline Keindahan & 0,07 & 0,05 & 0,04 & 0,06 & 0,06 & 0,06 & 0,10 & 0,10 & 0,54 & 0,07 \\
\hline Sabuk & 0,05 & 0,03 & 0,02 & 0,02 & 0,02 & 0,02 & 0,03 & 0,03 & 0,24 & 0,03 \\
\hline Tim & 0,05 & 0,03 & 0,02 & 0,02 & 0,02 & 0,02 & 0,03 & 0,03 & 0,24 & 0,03 \\
\hline \multicolumn{2}{|l|}{ Jumlah } & 28,65 & & & & & & & & \\
\hline \multicolumn{2}{|c|}{$\lambda$ maks $=$ jumlah/n } & 3,582 & & & & & & & & \\
\hline \multicolumn{2}{|c|}{$C \mathrm{Cl}=(\lambda \mathrm{\lambda}$ maks-n $n) / \mathrm{n})$} & $-0,55$ & & & & & & & & \\
\hline \multicolumn{2}{|l|}{$C R=(C / / \mathbb{R})$} & $-0,39$ & & & & & & & & \\
\hline
\end{tabular}

Pada tabel 2, maka didapatkan nilai eigen atau nilai prioritas, nilai matriks ( $\lambda$ Maks), Consistency Index (CI), dan nilai Consistency Ratio (CR), dengan ketentuan :

$$
\begin{aligned}
& \lambda \text { Maks }=\text { Jumlah/Jumlah Data } \\
& \lambda \text { Maks }=28,65 / 8=3,582
\end{aligned}
$$

Dikarenakan matrik berordo 8 (8 kriteria), maka nilai CI (Consistency Index) yang dihasilkan adalah:

$$
\mathrm{CI}=\frac{(\lambda m a k s-n)}{(n)}=\frac{(3,582-8)}{(8)}=-0,6
$$

Untuk $\mathrm{n}=8, \mathrm{RI}=1,41$ maka diperolehlah nilai $\mathrm{CR}$ (Consistency Ratio) adalah :

$$
\mathrm{CR}=\frac{C I}{R I}=\frac{-0,6}{1,41}=-0,4
$$

Berdasarkan pada prioritashasil dari tabel 2, dapat dilihat bahwa kriteria yang penting adalah Kedisiplinan, Sikap, Kerajinan, Teknik, Daya Tahan, Keindahan, Sabuk, dan Tim.

Selanjutnya dilakukanlah perhitungan terhadap matrik perbandingan alternatif padasetiap kriteria yang ada. Cara melakukan perhitungannya tetap

\begin{tabular}{|c|c|c|c|c|c|c|c|}
\hline & A & $B$ & C & D & $E$ & Jumlah & Prioritas \\
\hline A & 0,21 & 0,29 & 0,26 & 0,29 & 0,18 & 1,23 & 0,25 \\
\hline$B$ & 0,07 & 0,10 & 0,16 & 0,10 & 0,11 & 0,53 & 0,11 \\
\hline c & 0,04 & 0,03 & 0,05 & 0,03 & 0,08 & 0,23 & 0,05 \\
\hline D & 0,07 & 0,10 & 0,16 & 0,10 & 0,11 & 0,53 & 0,11 \\
\hline $\mathrm{E}$ & 0,62 & 0,48 & 0,37 & 0,48 & 0,53 & 2,49 & 0,50 \\
\hline \multicolumn{2}{|c|}{ Jumlah } & 17,67 & & & & & \\
\hline \multicolumn{2}{|c|}{$\lambda$ maks $=$ jumlah $/ \mathbf{n}$} & 3,53 & & & & & \\
\hline \multicolumn{2}{|c|}{$\mathrm{Cl}=((\lambda$ maks-n $) / \mathrm{n})$} & $-0,29$ & & & & & \\
\hline \multicolumn{2}{|c|}{$C R=(C I / I R)$} & $-0,26$ & & & & & \\
\hline
\end{tabular}
sama. Tabel 3 merupakan hasil normalisasi pada matriks berpasangan kriteria kedisiplinan.
Tabel 3. Nilai Bobot Kriteria Kedisiplinan

Pada tabel 3, didapatkan nilai eigen atau nilai prioritas, nilai matriks ( $\lambda$ Maks), Consistency Index (CI), dan nilai Consistency Ratio (CR), dengan ketentuan :

$$
\begin{aligned}
& \lambda \text { Maks }=\text { Jumlah/ Jumlah Data } \\
& \lambda \text { Maks }=17,67 / 5=3,53 \\
& \mathrm{CI}=\frac{(\lambda \text { maks }-n)}{(n)}=\frac{(3,53-5)}{(5)}=-0,29
\end{aligned}
$$

Untuk $\mathrm{n}=5, \mathrm{RI}=1,12$ maka diperolehlah nilai $\mathrm{CR}$ (Consistency Ratio) adalah :

$$
\mathrm{CR}=\frac{C I}{R I}=\frac{-0,29}{1,12}=-0,26
$$

\begin{tabular}{|c|c|c|c|c|c|c|c|}
\hline & A & $B$ & c & D & E & Jumlah & Prioritas \\
\hline A & 0,21 & 0,24 & 0,24 & 0,40 & 0,17 & 1,25 & 0,25 \\
\hline B & 0,07 & 0,08 & 0,14 & 0,04 & 0,10 & 0,44 & 0,09 \\
\hline $\mathrm{C}$ & 0,04 & 0,03 & 0,05 & 0,03 & 0,07 & 0,21 & 0,04 \\
\hline$D$ & 0,07 & 0,24 & 0,24 & 0,13 & 0,17 & 0,85 & 0,17 \\
\hline $\mathrm{E}$ & 0,62 & 0,41 & 0,33 & 0,40 & 0,50 & 2,25 & 0,45 \\
\hline \multicolumn{2}{|c|}{ Jumlah } & 17,66 & & & & & \\
\hline \multicolumn{2}{|c|}{$\lambda$ maks = jumlah/n } & 3,53 & & & & & \\
\hline \multicolumn{2}{|c|}{$\mathrm{Cl}=((\lambda$ maks-n $) / \mathrm{n})$} & $-0,29$ & & & & & \\
\hline \multicolumn{2}{|c|}{$C R=(C I / I R)$} & $-0,26$ & & & & & \\
\hline
\end{tabular}

Berdasarkan pada prioritas hasil dari tabel 3, dapat dilihat bahwa alternatif yang memiliki nilai yang lebih baik dalam kedisiplinan, adalah E, A, B, D, dan C.

Untuk matrik berpasangan kriteria sikap, dapat dilihat pada Tabel 4.

Tabel 4. Nilai Bobot Kriteria Sikap

Pada tabel 4, didapatkan nilai eigen atau nilai prioritas, nilai matriks ( $\lambda$ Maks), Consistency Index (CI), dan nilai Consistency Ratio (CR), dengan ketentuan :

$$
\begin{aligned}
& \lambda \text { Maks }=\text { Jumlah/ Jumlah Data } \\
& \lambda \text { Maks }=17,66 / 5=3,53 \\
& \mathrm{CI}=\frac{(\lambda m a k s-n)}{(n)}=\frac{(3,53-5)}{(5)}=-0,29
\end{aligned}
$$

Untuk $\mathrm{n}=5, \mathrm{RI}=1,12$ maka diperolehlah nilai $\mathrm{CR}$ (Consistency Ratio) adalah :

$$
\mathrm{CR}=\frac{C I}{R I}=\frac{-0,29}{1,12}=-0,26
$$

Berdasarkan pada prioritas hasil dari tabel 4, dapat dilihat bahwa alternatif yang memiliki nilai yang lebih baik dalam sikap, adalah E, A, D, B, dan C.

Untuk matrik berpasangan kriteria kerajinan, dapat dilihat pada Tabel 5. 
Tabel 5. Nilai Bobot Kriteria Kerajinan

\begin{tabular}{|c|c|c|c|c|c|c|c|}
\hline & A & B & c & D & $\mathrm{E}$ & Jumlah & Prioritas \\
\hline A & 0,21 & 0,29 & 0,26 & 0,29 & 0,18 & 1,23 & 0,25 \\
\hline B & 0,07 & 0,10 & 0,16 & 0,10 & 0,11 & 0,53 & 0,11 \\
\hline c & 0,04 & 0,03 & 0,05 & 0,03 & 0,08 & 0,23 & 0,05 \\
\hline D & 0,07 & 0,10 & 0,16 & 0,10 & 0,11 & 0,53 & 0,11 \\
\hline $\mathrm{E}$ & 0,62 & 0,48 & 0,37 & 0,48 & 0,53 & 2,49 & 0,50 \\
\hline \multicolumn{2}{|c|}{ Jumlah } & 17,67 & & & & & \\
\hline \multicolumn{2}{|c|}{$\lambda$ maks $=$ jumlah $/ \mathbf{n}$} & 3,53 & & & & & \\
\hline \multicolumn{2}{|c|}{$\mathrm{Cl}=((\lambda$ maks $-\mathrm{n}) / \mathrm{n})$} & $-0,29$ & & & & & \\
\hline \multicolumn{2}{|c|}{$\mathrm{CR}=(\mathrm{Cl} / \mathrm{IR})$} & $-0,26$ & & & & & \\
\hline
\end{tabular}

Pada tabel 5, maka didapatkan nilai eigen atau nilai prioritas, nilai matriks ( $\lambda$ Maks), Consistency Index (CI), dan nilai Consistency Ratio (CR), dengan ketentuan :

$$
\begin{aligned}
& \lambda \text { Maks }=\text { Jumlah/ Jumlah Data } \\
& \lambda \text { Maks }=17,67 / 5=3,53 \\
& \mathrm{CI}=\frac{(\lambda m a k s-n)}{(n)}=\frac{(3,53-5)}{(5)}=-0,29
\end{aligned}
$$

Untuk $\mathrm{n}=5, \mathrm{RI}=1,12$ maka diperolehlah nilai $\mathrm{CR}$ (Consistency Ratio) adalah :

$$
\mathrm{CR}=\frac{C I}{R I}=\frac{-0,29}{1,12}=-0,26
$$

Berdasarkan pada prioritas hasil dari tabel 5, dapat dilihat bahwa alternatif yang memiliki nilai yang lebih baik dalam kerajinan, adalah E, A, D, B, dan C.

\begin{tabular}{|c|c|c|c|c|c|c|c|}
\hline & A & B & $\mathrm{C}$ & $\mathrm{D}$ & $\mathrm{E}$ & Jumlah & Prioritas \\
\hline A & 0,12 & 0,18 & 0,12 & 0,12 & 0,12 & 0,65 & 0,13 \\
\hline B & 0,04 & 0,06 & 0,07 & 0,07 & 0,04 & 0,28 & 0,06 \\
\hline C & 0,36 & 0,29 & 0,35 & 0,35 & 0,36 & 1,71 & 0,34 \\
\hline D & 0,36 & 0,29 & 0,35 & 0,35 & 0,36 & 1,71 & 0,34 \\
\hline $\mathrm{E}$ & 0,12 & 0,18 & 0,12 & 0,12 & 0,12 & 0,65 & 0,13 \\
\hline \multicolumn{2}{|c|}{ Jumlah } & 11,38 & & & & & \\
\hline \multicolumn{2}{|c|}{$\lambda$ maks $=$ jumlah $/ \mathrm{n}$} & 2,28 & & & & & \\
\hline \multicolumn{2}{|c|}{$\mathrm{Cl}=((\lambda$ maks-n $) / \mathrm{n})$} & $-0,54$ & & & & & \\
\hline \multicolumn{2}{|c|}{$\mathrm{CR}=(\mathrm{Cl} / \mathrm{IR})$} & $-0,49$ & & & & & \\
\hline
\end{tabular}

Untuk matrik berpasangan kriteria teknik, dapat dilihat pada Tabel 6 .

Tabel 6. Nilai Bobot Kriteria Teknik

Pada tabel 6, maka didapatkan nilai eigen atau nilai prioritas, nilai matriks ( $\lambda$ Maks), Consistency Index (CI), dan nilai Consistency Ratio (CR), dengan ketentuan :

$$
\begin{aligned}
& \lambda \text { Maks }=\text { Jumlah } / \text { Jumlah Data } \\
& \lambda \text { Maks }=11,38 / 5=2,28 \\
& \mathrm{CI}=\frac{(\lambda \text { maks }-n)}{(n)}=\frac{(2,28-5)}{(5)}=-0,54
\end{aligned}
$$

Untuk $\mathrm{n}=5, \mathrm{RI}=1,12$ maka diperolehlah nilai $\mathrm{CR}$ (Consistency Ratio) adalah :

$$
\mathrm{CR}=\frac{C I}{R I}=\frac{-0,49}{1,12}=-0,49
$$

\begin{tabular}{|c|c|c|c|c|c|c|c|}
\hline & A & B & $\mathrm{C}$ & $\mathrm{D}$ & $\mathrm{E}$ & Jumlah & Prioritas \\
\hline A & 0,35 & 0,36 & 0,27 & 0,29 & 0,35 & 1,62 & 0,32 \\
\hline B & 0,12 & 0,12 & 0,09 & 0,18 & 0,12 & 0,62 & 0,12 \\
\hline C & 0,12 & 0,12 & 0,09 & 0,18 & 0,12 & 0,62 & 0,12 \\
\hline D & 0,07 & 0,04 & 0,27 & 0,06 & 0,07 & 0,51 & 0,10 \\
\hline $\mathrm{E}$ & 0,35 & 0,36 & 0,27 & 0,29 & 0,35 & 1,62 & 0,32 \\
\hline \multicolumn{2}{|c|}{ Jumlah } & 13,20 & & & & & \\
\hline \multicolumn{2}{|c|}{$\lambda$ maks = jumlah $/ \mathbf{n}$} & 2,64 & & & & & \\
\hline \multicolumn{2}{|c|}{$\mathrm{Cl}=((\lambda$ maks $-\mathrm{n}) / \mathrm{n})$} & $-0,47$ & & & & & \\
\hline \multicolumn{2}{|c|}{$\mathrm{CR}=(\mathrm{Cl} / \mathrm{IR})$} & $-0,42$ & & & & & \\
\hline
\end{tabular}

Berdasarkan pada prioritas hasil dari tabel 6, dapat dilihat bahwa alternatif yang memiliki nilai yang lebih baik dalam teknik, adalah C, D,A, E, dan C.

Untuk matrik berpasangan kriteria daya tahan, dapat dilihat pada Tabel 7.
Tabel 7. Nilai Bobot Kriteria Daya Tahan

Pada tabel 7, maka didapatkan nilai eigen atau nilai prioritas, nilai matriks ( $\lambda$ Maks), Consistency Index (CI), dan nilai Consistency Ratio (CR), dengan ketentuan :

$$
\begin{aligned}
& \lambda \text { Maks }=\text { Jumlah/ Jumlah Data } \\
& \lambda \text { Maks }=13,20 / 5=2,64 \\
& \mathrm{CI}=\frac{(\lambda m a k s-n)}{(n)}=\frac{(2,64-5)}{(5)}=-0,47
\end{aligned}
$$

Untuk $\mathrm{n}=5, \mathrm{RI}=1,12$ maka diperolehlah nilai $\mathrm{CR}$ (Consistency Ratio) adalah :

$$
\mathrm{CR}=\frac{C I}{R I}=\frac{-0,47}{1,12}=-0,42
$$

Berdasarkan pada prioritas hasil dari tabel 7, dapat dilihat bahwa alternatif yang memiliki nilai yang lebih baik dalam daya tahan, adalah A, E,B, C, dan D.

Untuk matrik berpasangan kriteria keindahan, dapat dilihat pada Tabel 8.

Tabel 8. Nilai Bobot Kriteria Keindahan

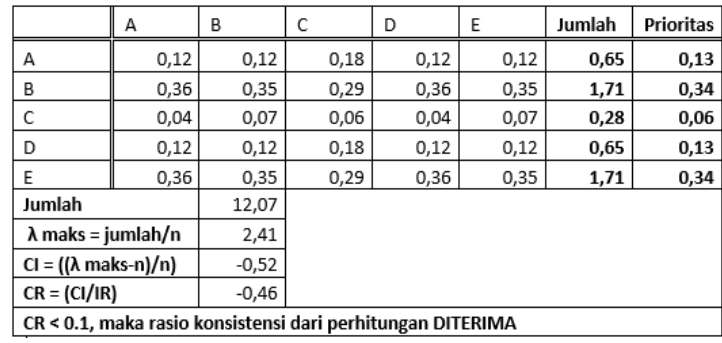

Pada tabel 8, didapatkan nilai eigen atau nilai prioritas, nilai matriks ( $\lambda$ Maks), Consistency Index (CI), dan nilai Consistency Ratio (CR), dengan ketentuan :

$$
\begin{aligned}
& \lambda \text { Maks }=\text { Jumlah/ Jumlah Data } \\
& \lambda \text { Maks }=12,07 / 5=2,41 \\
& \text { CI }=\frac{(\lambda m a k s-n)}{(n)}=\frac{(2,41-5)}{(5)}=-0,52
\end{aligned}
$$

Untuk n=5, RI=1,12 maka diperolehlah nilai $\mathrm{CR}$ (Consistency Ratio) adalah :

$$
\mathrm{CR}=\frac{C I}{R I}=\frac{-0,41}{1,12}=-0,46
$$

Berdasarkan pada prioritas hasil dari tabel 8, dapat dilihat bahwa alternatif yang memiliki nilai yang lebih baik dalam keindahanan, adalah B, E,A, D, dan $\mathrm{C}$.

Untuk matrik berpasangan kriteria tim, dapat dilihat pada Tabel 9. 
Tabel 9. Nilai Bobot Kriteria Tim

\begin{tabular}{|c|c|c|c|c|c|c|c|}
\hline & A & B & $\mathrm{C}$ & $\mathrm{D}$ & $\mathrm{E}$ & Jumlah & Prioritas \\
\hline A & 0,23 & 0,23 & 0,23 & 0,23 & 0,23 & 1,15 & 0,23 \\
\hline B & 0,08 & 0,08 & 0,08 & 0,08 & 0,08 & 0,38 & 0,08 \\
\hline c & 0,23 & 0,23 & 0,23 & 0,23 & 0,23 & 1,15 & 0,23 \\
\hline D & 0,23 & 0,23 & 0,23 & 0,23 & 0,23 & 1,15 & 0,23 \\
\hline $\mathrm{E}$ & 0,23 & 0,23 & 0,23 & 0,23 & 0,23 & 1,15 & 0,23 \\
\hline \multicolumn{2}{|c|}{ Jumlah } & 8,86 & & & & & \\
\hline \multicolumn{2}{|c|}{$\lambda$ maks $=$ jumlah $/ \mathbf{n}$} & 1,77 & & & & & \\
\hline \multicolumn{2}{|c|}{$\mathrm{Cl}=((\lambda$ maks $-\mathrm{n}) / \mathrm{n})$} & $-0,65$ & & & & & \\
\hline \multicolumn{2}{|c|}{$\mathrm{CR}=(\mathrm{Cl} / \mathrm{IR})$} & $-0,58$ & & & & & \\
\hline
\end{tabular}

Pada tabel 9, didapatkan nilai eigen atau nilai prioritas, nilai matriks ( $\lambda$ Maks), Consistency Index (CI), dan nilai Consistency Ratio (CR), dengan ketentuan :

$$
\begin{aligned}
& \lambda \text { Maks }=\text { Jumlah/ Jumlah Data } \\
& \lambda \text { Maks }=8,86 / 5=1,77 \\
& \mathrm{CI}=\frac{(\lambda m a k s-n)}{(n)}=\frac{(1,77-5)}{(5)}=-0,65
\end{aligned}
$$

Untuk $\mathrm{n}=5, \mathrm{RI}=1,12$ maka diperolehlah nilai $\mathrm{CR}$ (Consistency Ratio) adalah :

$$
\mathrm{CR}=\frac{C I}{R I}=\frac{-0,65}{1,12}=-0,58
$$

Berdasarkan pada prioritas hasil dari tabel 9, dapat dilihat bahwa alternatif yang memiliki nilai yang lebih baik dalam tim, adalah A, C, D, E, dan B.

Untuk matrik berpasangan sub kriteria hijau, dapat dilihat pada Tabel 10.

\section{Tabel 10. Nilai Bobot Sub Kriteria Hijau}

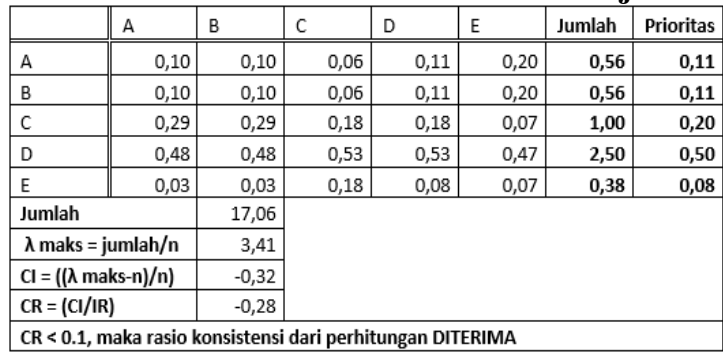

Pada tabel 10, didapatkan nilai eigen atau nilai prioritas, nilai matriks ( $\lambda$ Maks), Consistency Index (CI), dan nilai Consistency Ratio (CR), dengan ketentuan :

$$
\begin{aligned}
& \lambda \text { Maks }=\text { Jumlah/ Jumlah Data } \\
& \lambda \text { Maks }=17,06 / 5=3,41 \\
& \text { CI }=\frac{(\lambda m a k s-n)}{(n)}=\frac{(3,41-5)}{(5)}=-0,32
\end{aligned}
$$

Untuk $\mathrm{n}=5, \mathrm{RI}=1,12$ maka diperolehlah nilai $\mathrm{CR}$ (Consistency Ratio) adalah :

$$
\mathrm{CR}=\frac{C I}{R I}=\frac{-0,32}{1,12}=-0,28
$$

\begin{tabular}{|c|c|c|c|c|c|c|c|}
\hline & A & B & C & D & E & Jumlah & Prioritas \\
\hline A & 0,10 & 0,10 & 0,06 & 0,11 & 0,20 & 0,56 & 0,11 \\
\hline B & 0,10 & 0,10 & 0,06 & 0,11 & 0,20 & 0,56 & 0,11 \\
\hline c & 0,29 & 0,29 & 0,18 & 0,18 & 0,07 & 1,00 & 0,20 \\
\hline D & 0,48 & 0,48 & 0,53 & 0,53 & 0,47 & 2,50 & 0,50 \\
\hline$E$ & 0,03 & 0,03 & 0,18 & 0,08 & 0,07 & 0,38 & 0,08 \\
\hline \multicolumn{2}{|c|}{ Jumlah } & 17,06 & & & & & \\
\hline \multicolumn{2}{|c|}{$\lambda$ maks = jumlah/n } & 3,41 & & & & & \\
\hline \multicolumn{2}{|c|}{$\mathrm{Cl}=((\lambda$ maks $-n) / \mathrm{n})$} & $-0,32$ & & & & & \\
\hline \multicolumn{2}{|c|}{$\mathrm{CR}=(\mathrm{Cl} / \mathrm{IR})$} & $-0,28$ & & & & & \\
\hline
\end{tabular}

Berdasarkan pada prioritas hasil dari tabel 10, dapat dilihat bahwa alternatif yang memiliki nilai yang lebih baik dalam sub kriteria hijau, adalah D, C, A, B, dan E.

Untuk matrik berpasangan sub kriteria biru, dapat dilihat pada Tabel 11.
Tabel 11. Nilai Bobot Sub Kriteria Biru

Pada tabel 11, didapatkan nilai eigen atau nilai prioritas, nilai matriks ( $\lambda$ Maks), Consistency Index (CI), dan nilai Consistency Ratio (CR), dengan ketentuan :

$$
\begin{aligned}
& \lambda \text { Maks }=\text { Jumlah/ Jumlah Data } \\
& \lambda \text { Maks }=17,06 / 5=3,41 \\
& \mathrm{CI}=\frac{(\lambda m a k s-n)}{(n)}=\frac{(3,41-5)}{(5)}=-0,32
\end{aligned}
$$

\begin{tabular}{|c|c|c|c|c|c|c|c|}
\hline & A & B & C & D & E & Jumlah & Prioritas \\
\hline A & 0,10 & 0,10 & 0,06 & 0,11 & 0,20 & 0,56 & 0,11 \\
\hline B & 0,10 & 0,10 & 0,06 & 0,11 & 0,20 & 0,56 & 0,11 \\
\hline C & 0,29 & 0,29 & 0,18 & 0,18 & 0,07 & 1,00 & 0,20 \\
\hline D & 0,48 & 0,48 & 0,53 & 0,53 & 0,47 & 2,50 & 0,50 \\
\hline $\mathrm{E}$ & 0,03 & 0,03 & 0,18 & 0,08 & 0,07 & 0,38 & 0,08 \\
\hline \multicolumn{2}{|c|}{ Jumlah } & 17,06 & & & & & \\
\hline \multicolumn{2}{|c|}{$\lambda$ maks $=$ jumlah $/ \mathbf{n}$} & 3,41 & & & & & \\
\hline \multicolumn{2}{|c|}{$\mathrm{Cl}=((\lambda$ maks-n $) / \mathrm{n})$} & $-0,32$ & & & & & \\
\hline \multicolumn{2}{|c|}{$\mathrm{CR}=(\mathrm{Cl} / \mathrm{IR})$} & $-0,28$ & & & & & \\
\hline
\end{tabular}

Untuk $\mathrm{n}=5, \mathrm{RI}=1,12$ maka diperolehlah nilai $\mathrm{CR}$ (Consistency Ratio) adalah :

$$
\mathrm{CR}=\frac{C I}{R I}=\frac{-0,32}{1,12}=-0,28
$$

Berdasarkan pada prioritas hasil dari tabel 11, dapat dilihat bahwa alternatif yang memiliki nilai yang lebih baik dalam sub kriteria biru, adalah D, C, A, B, dan E.

Untuk matrik berpasangan sub kriteria merah, dapat dilihat pada Tabel 12.

Tabel 12. Nilai Bobot Sub Kriteria Merah

Pada tabel 12, didapatkan nilai eigen atau nilai prioritas, nilai matriks ( $\lambda$ Maks), Consistency Index (CI), dan nilai Consistency Ratio (CR), dengan ketentuan :

$$
\begin{aligned}
& \lambda \text { Maks }=\text { Jumlah/ Jumlah Data } \\
& \lambda \text { Maks }=17,06 / 5=3,41 \\
& \mathrm{CI}=\frac{(\lambda m a k s-n)}{(n)}=\frac{(3,41-5)}{(5)}=-0,32
\end{aligned}
$$

Untuk $\mathrm{n}=5, \mathrm{RI}=1,12$ maka diperolehlah nilai $\mathrm{CR}$ (Consistency Ratio) adalah :

$$
\mathrm{CR}=\frac{C I}{R I}=\frac{-0,32}{1,12}=-0,28
$$

Berdasarkan pada prioritas hasil dari tabel 12, dapat dilihat bahwa alternatif yang memiliki nilai yang lebih baik dalam sub kriteria hijau, adalah D, C, A, B, dan E.

Untuk matrik berpasangan sub kriteria hitam, dapat dilihat pada Tabel 13. 
Tabel 13. Nilai Bobot Sub Kriteria Hitam

\begin{tabular}{|c|c|c|c|c|c|c|c|}
\hline & A & B & C & D & E & Jumlah & Prioritas \\
\hline A & 0,10 & 0,10 & 0,06 & 0,11 & 0,20 & 0,56 & 0,11 \\
\hline B & 0,10 & 0,10 & 0,06 & 0,11 & 0,20 & 0,56 & 0,11 \\
\hline C & 0,29 & 0,29 & 0,18 & 0,18 & 0,07 & 1,00 & 0,20 \\
\hline D & 0,48 & 0,48 & 0,53 & 0,53 & 0,47 & 2,50 & 0,50 \\
\hline $\mathrm{E}$ & 0,03 & 0,03 & 0,18 & 0,08 & 0,07 & 0,38 & 0,08 \\
\hline \multicolumn{2}{|c|}{ Jumlah } & 17,06 & & & & & \\
\hline \multicolumn{2}{|c|}{$\lambda$ maks $=$ jumlah $/ \mathbf{n}$} & 3,41 & & & & & \\
\hline \multicolumn{2}{|c|}{$\mathrm{Cl}=((\lambda$ maks-n $) / \mathrm{n})$} & $-0,32$ & & & & & \\
\hline \multicolumn{2}{|c|}{$\mathrm{CR}=(\mathrm{Cl} / \mathrm{IR})$} & $-0,28$ & & & & & \\
\hline
\end{tabular}

Pada tabel 13, didapatkan nilai eigen atau nilai prioritas, nilai matriks ( $\lambda$ Maks), Consistency Index (CI), dan nilai Consistency Ratio (CR), dengan ketentuan :

$$
\begin{aligned}
& \lambda \text { Maks }=\text { Jumlah/ Jumlah Data } \\
& \lambda \text { Maks }=17,06 / 5=3,41 \\
& \mathrm{CI}=\frac{(\lambda m a k s-n)}{(n)}=\frac{(3,41-5)}{(5)}=-0,32
\end{aligned}
$$

Untuk $\mathrm{n}=5, \mathrm{RI}=1,12$ maka diperolehlah nilai $\mathrm{CR}$ (Consistency Ratio) adalah :

$$
\mathrm{CR}=\frac{C I}{R I}=\frac{-0,32}{1,12}=-0,28
$$

Berdasarkan pada prioritas hasil dari tabel 13, dapat dilihat bahwa alternatif yang memiliki nilai yang lebih baik dalam sub kriteria hitam, adalah D, C, A, B, dan E.

Setelah mendapatkan nilai bobot keseluruhan, dimulai dari bobot kriteria dan bobot sub kriteria, maka diperoleh total bobot keseluruhan yang menjadi patokan dalam memilih alternatif yang tepat menjadi atlet poomsae berdasarkan nilai prioritas yang didapatkan pada setiap matrik.

$\begin{aligned} \text { Alternatif } \mathrm{A}= & (0,32 * 0,25)+(0,27 * 0,25)+ \\ & (0,15 * 0,25)+(0,07 * 0,13)+ \\ & (0,07 * 0,32)+(0,07 * 0,13)+ \\ & ((0,03 * 0,06) * 0,11 \\ & ((0,03 * 0,12) * 0,11)+ \\ & ((0,03 * 0,26) * 0,11)+ \\ & ((0,03 * 0,56) * 0,11)+(0,03 * 0,23) \\ = & 0,23\end{aligned}$

$\begin{aligned} \text { Alternatif } \mathrm{B}= & (0,32 * 0,11)+(0,27 * 0,09)+ \\ & (0,15 * 0,11)+(0,07 * 0,06)+ \\ & (0,07 * 0,12)+(0,07 * 0,34)+ \\ & ((0,03 * 0,06) * 0,11) \\ & ((0,03 * 0,12) * 0,11)+ \\ & ((0,03 * 0,26) * 0,11)+ \\ & ((0,03 * 0,56) * 0,11)+(0,03 * 0,08) \\ = & 0,11\end{aligned}$

$$
\begin{aligned}
\text { Alternatif } \mathrm{C}= & (0,32 * 0,05)+(0,27 * 0,04)+ \\
& (0,15 * 0,05)+(0,07 * 0,34)+ \\
& (0,07 * 0,12)+(0,07 * 0,06)+ \\
& ((0,03 * 0,06) * 0,20) \\
& \left((0,03 * 0,12)^{*} 0,20\right) \\
& \left((0,03 * 0,26)^{*} 0,20\right) \\
& \left((0,03 * 0,56)^{*} 0,20\right)+(0,03 * 0,23) \\
= & 0,08
\end{aligned}
$$

$$
\begin{aligned}
\text { Alternatif } \mathrm{D}= & (0,32 * 0,11)+(0,27 * 0,17)+ \\
& (0,15 * 0,11)+(0,07 * 0,34)+ \\
& (0,07 * 0,10)+(0,07 * 0,13)+ \\
& ((0,03 * 0,06) * 0,50) \\
& ((0,03 * 0,12) * 0,50) \\
& ((0,03 * 0,26) * 0,50)+ \\
& ((0,03 * 0,56) * 0,50)+(0,03 * 0,23) \\
= & 0,16
\end{aligned}
$$$$
\begin{aligned}
\text { Alternatif } \mathrm{E}= & (0,32 * 0,50)+(0,27 * 0,45)+ \\
& (0,15 * 0,50)+(0,07 * 0,13)+ \\
& (0,07 * 0,32)+(0,07 * 0,34)+ \\
& ((0,03 * 0,06) * 0,08) \\
& ((0,03 * 0,12) * 0,08) \\
& ((0,03 * 0,26) * 0,08)+ \\
& ((0,03 * 0,56) * 0,50)+(0,03 * 0,23) \\
& =0,42
\end{aligned}
$$

Berdasarkan hasil perhitungan nilai bobot dari setiap kriteria dan sub kriteria, maka hasil pengurutan adalah $\mathrm{E}(0,42), \mathrm{A}(0,23), \mathrm{D}(0,16)$, $\mathrm{B}(0,11)$, dan $\mathrm{C}(0,08)$.

\section{SIMPULAN}

Analytical Hierarchy Process (AHP) merupakan metode yang mudah untuk diterapkan dalam pengambilan keputusan multi-kriteria, terlebih mudah untuk dipahami dan efektif untuk data kualitatif dan kuantitatif.Sudah banyak peneiliti yang juga menerapkan metode ini untuk membantu dalam pengambilan keputusan. Jadi, berdasarkan hasil dari penelitian yang telah di lakukan, metode ini dapat memberikan masukan bagi pelatih yang akan memilih anggotanya untuk menjadi atlet di bidang poomsae. Kemudahan dalam mendapatkan informasi yang diperoleh pun menjadi nilai tambahan keefektifan dalam menyeleksi atlet pilihan. Dari data yang diolah, maka didapatkan bahwa diantara beberapa alternatif, maka didiapatkan prioritas yang bisa dijadikan atlet untuk mengikuti kejuaraan poomsae. Jika ada empat calon yang akan di ambil, maka pilihan akan jatuh pada E $(042)$, A $(0,23)$, D $(0,16)$, dan $\mathrm{B}(0,11)$. Dengan pemanfaatan metode ini, maka bisa memberikan motivasi bagi para anggota yang ingin menjadi calon atlet agar bisamemaksimalkan diri agar bisa sesuai dengan kriteria yang sudah ditentukan.

\section{DAFTAR PUSTAKA}

Doraid Dalalah, F. A.-O., \& Mohammed Hayajneh 2010. "Application of the Analytic Hierarchy Process (AHP) in Multi Criteria Analysis of the Selection of Cranes." Jordan Journal of Mechanical and Industrial Engineering, Volume 4, Number 5.

R. C. Claudio, et al. 2016. "Use of Analytical Hierarchy Process (AHP) to identify the preference of accounting experts regarding the 
company valuation method in accounting expertise", Journal of Education and Research in Accounting Volume 10, No. 1.

Adriyendi dan Yeni Melia (2013). "DSS using AHP in Selection of Lecturer." International Journal of Advanced Science and Technology. 52. 35-43.

Fevi Syaifoelida, et al (2013). "The Design Preferences Decision Using the Analytical Hierarchy Process towards Kansei Engineering Approach: Spectacles Design." International Journal of Application or Innovation in Engineering \& Management. 2. 269-274.

-Setiawan, Adi, et al. 2014. "Application of AHP Method in Determining Priorities of Conversion of Unusedland to Food Land in Minahasa Tenggara", International Journal of Computer Application Volume 89, No. 8.

-Magdalena, H. (2012). "Sistem Pendukung Keputusan Untuk Menentukan Mahasiswa Lulusan Terbaik di Perguruan Tinggi (Studi Kasus STMIK Atma Luhur Pangkalpinang)", Seminar Nasional Teknologi Informasi dan Komunikasi.

Doraid Dalalah, F. A.-O., \& Mohammed Hayajneh 2010. "Application of the Analytic Hierarchy Process (AHP) in Multi Criteria Analysis of the Selection of Cranes." Jordan Journal of Mechanical and Industrial Engineering, Volume 4, Number 5.

R. C. Claudio, et al. 2016. "Use of Analytical Hierarchy Process (AHP) to identify the preference of accounting experts regarding the company valuation method in accounting expertise", Journal of Education and Research in Accounting Volume 10, No. 1.

Adriyendi dan Yeni Melia (2013). "DSS using AHP in Selection of Lecturer." International Journal of Advanced Science and Technology. 52. 35-43.

Fevi Syaifoelida, et al (2013). "The Design Preferences Decision Using the Analytical Hierarchy Process towards Kansei Engineering Approach: Spectacles Design." International Journal of Application or Innovation in Engineering \& Management. 2. 269-274.

-Setiawan, Adi, et al. 2014. "Application of AHP Method in Determining Priorities of Conversion of Unusedland to Food Land in Minahasa Tenggara", International Journal of Computer Application Volume 89, No. 8.

-Magdalena, H. (2012). "Sistem Pendukung Keputusan Untuk Menentukan Mahasiswa Lulusan Terbaik di Perguruan Tinggi (Studi Kasus STMIK Atma Luhur Pangkalpinang)",
Seminar Nasional Teknologi Informasi dan Komunikasi.

Muhammad Reza Utama, H. S. R., dan R. Hari Adianto (2014). "Usulan Pemilihan Lokasi National Conference AIESEC LC Bandung dengan Menggunakan Metode Analytical Hierarchy Process", Jurnal Online Institut Teknologi Nasional Volume. 01, No. 04.

-Petrus Wolo, I. D. R., \& Andia Dekrita (2012).

"Strategi Peningkatan Daya Saing Produk

Sarung Blikonblewut Dengan Menggunakan Metode Analytical Hierarchy Process", Seminar Nasional Teknologi Informasi dan Komunikasi.

-Sweta Bhattacharya, S. B., \& Bhawana Bhopte 2012. "Implementation of Analytical Hierarchical Process to support decisions in Employee Performance Appraisal ", International Journal of Computer Science and Information Technology \& Security Volume 2, No. 2.

-Rika Yunitarini. 2013. "Sistem Pendukung Keputusan Pemilihan Penyiar Radio Terbaik", Jurnal Ilmiah Mikrotek. 1. 43-52. 